\title{
INVESTIGATING THE TEFL/ESP PRACTITIONER'S DILEMMATIC CURRENT STATUS IN THE IRAQI KURDISTAN REGION
}

\author{
Ahmed Khalis Shalan* and Ghayda Ali MUHAMmed ** \\ "Nawroz University-Kurdistan Region-Iraq \\ ${ }^{* *}$ University of Zakho-Kurdistan Region-Iraq
}

(Received: December 6, 2016; Accepted for Publication: May 22, 2017)

\begin{abstract}
As a specialist in TEFL/ESP, the writers of this research-paper submitted a proposal of a symposium about TEFL/ESP titled "Teaching ESP in Iraqi-Kurdistan Region: Reality \& Prospects", to the Deanery of the College of Languages/ Nawroz University in collaboration with the College of Administration \& Economics/ Nawroz University. Four researches from three universities in Dohuk Governorate area delivered six papers on the platform of Kurdistan Hall/ Nawroz University.

Meanwhile, it was presumed in advance that the symposium attending-practitioners who usually teach the ESP programs would be of two types majoring:

- (Type 1) practitioners with TEFL-qualification, and

- (Type 2) practitioners with no TEFL-qualification but they teach ESP programs depending on the experience of using English as medium of instruction gained when they were postgraduatestudents; their medium of study was English.

Hence, the writers of this research-paper in advance designed and prepared two versions of questionnaire forms to investigate the two types attending-practitioners' readiness to teach ESP. The questionnaire versions was built upon the six dimensions (each with 3 parameters) of Kumaravadivelu's cyclic module of TEFL (2012); aiming at investigating the extent the two types of practitioners could realize during their performances of teaching an ESP program, in order then to make a sort of comparison between the two groups' achievements.

Two hypotheses were in mind:

- the ESP practitioners with TEFL-qualification could not fairly fulfill the objectives of teaching the scientific programs other than the TEFL programs, though they majored in English, and

- the ESP practitioners with non-TEFL-qualification could not fairly fulfill the objectives of their major-scientific-programs with no experience of how to use English as a medium of study.

Distributing the questionnaire forms, collecting them back, analyzing the data, gathering the results, and making comparison between the 2-type-practitioners' responses, the following findings were reached:

- The two investigated types of ESP practitioners could fairly satisfy the objectives built on Kumaravadivelu's cyclic module.

- Significant differences were marked in favor of the type 2 practitioners, in respect of satisfying the needs of Kumaravadivelu's cyclic module.

Finally, certain recommendations were made about how to develop an advance ESP discipline.
\end{abstract}

KEY TERMS: ESP, EAP, CLIL, LSP. NLE, NDE, Genre, and Practitioner

\section{1- INTRODUCTION}

$\Delta \begin{aligned} & \text { cartload of bricks is not a house; we } \\ & \text { want a principle, a system, and }\end{aligned}$ integration."

(Michel Serres 2004:2 - cited in Kumaravadivelu 2012: 1)

Though it is not easy to grasp whollysatisfactory answers for certain crucial questions, still the need is already there to find a specific rationale to good teaching and teachers' preparation. This is, because teacher preparation, as a demand, would help us to find the ONE needed for specific educational-situations. Hence, the concern of using English as a medium of instruction has been brought in the view during the few recent decades and to be under discussions as 
one of very important and vital topics in the teaching-learning communities. Therefore, in our academic institutions and among the academics in general, a clear cut differentiation has not been yet recognized between two situations the English language is found to be involved in:

- a situation in which English is found at the same time as a target and medium of study, and

- another situation in which English is found as only a medium of study.

Unfortunately, most of the academics in our institutions might have only little knowledge about the rationale of each type of the above-mentioned two types of pedagogical situations. In the first type of situation English is found to be at the same time; as a means of study and as the core scientific-subject of study, while in the second type of situation English is found only as a means to study core scientificsubjects other than the English language scientific-subjects. Hence, discussions has initiated, among the TEFL communities, to define the two types of situations where English is found as a language of instruction. This, subsequently, paved the way to the rise of relevant technical terms, related in particular to the second type of situation, i.e., using English only as a medium of instruction, such as English for Specific (Special) Purposes (ESP), English for Academic Purposes (EAP), Content and Language Integrated Learning (CLIL), Language for Special Purposes (LSP) NonDepartmental English (NDE), NonLinguistic English (NLE), etc., and not to mention the appearance of tens of relevant sub-terms to stand for various uses of English as a medium of instruction, media, business, tourism, etc.

As a matter of fact, knowing such a distinction between two cases of using English in the academic environment, very important relevant questions might be cast about the core values related to each situation English is used as a means of instruction, and not to mention questions about the English programs and curricula adopted for the two cases, and also matters related to the teacher needed in each one of the two cases.
During the academic year 2015-2016 a very important Symposium was held in Kurdistan Hall/ Nawroz University/ Duhok City under the title 'ESP Teaching in Kurdistan: Reality and Perspectives'. The Symposium most-likely was a unique event of the kind in Kurdistan Region-Iraq, if not in Iraq as whole.

A multitude of academics and officials from Duhok Governorate area's universities (Zakho, Duhok, Jeehan, and Nawroz) attended the event whether as presenters or only attendees. The attendees of the event were assumingly-ranged among two types:

1- Instructors majored in EFL and as practitioners, they teach ESP, EAP, CLIL, etc., and

2- Instructors majored in scientific branches other than the EFL sciences, and as practitioners, they use English as a medium of instruction,

The topics at issue in the symposium's table of discussions were:

1- The Experience of South-East Asian Countries in ESPT (Nawroz Uni.)

2- Designing an ESP Program for the Student of Management (Duhok Uni.)

3- Teaching English to Non-departmental Students: Confused Subject (Nawroz Uni.)

4- Problems facing ESPT. (Zakho Uni.)

5- The Teacher of English as Nonspecialized Subject. (Nawroz Uni.)

6- The Global Experience in ESPT Compared to its Counterpart in Iraq and Kurdistan.(Nawroz Uni.)

Hence, stimulated by the type of the Symposium's presumed academicattendance, the researchers arranged and designed, in advance, two samples of questionnaire-forms to be distributed during the Symposium's event to inquire, through specific methodological means, the abovementioned assumed attendees according to each type of the academic-attendee's concern over English as a medium of instruction,

\section{2- The Problem}

Using English as a medium of instruction, whether in a language classroom or in other scientific-branches' classrooms, has recently aroused controversy over certain pedagogical issues. For instance, even in a language classroom it largely happens to find academics majored in EFL sub-disciplines, 
but still they might not be well-qualified, in methods, to teach the meant sub-discipline as a professional. Consequently, it happened to find an academic who is, though majored in EFL, yet $s / h e$ is found, in many cases, to teach sciences that have nothing to do with their major linguistic-branch sciences (see the introduction-type 1). So, the question here is: Would such a teacher be fit enough to teach $\boldsymbol{E S P}$ (for convenience, ESP will henceforth stand for the other related terms). Likewise, it happened to find an academic who majored in a scientific-branch other than the EFL scientific-branches, and because English was the medium of their study while they were postgraduate-students, they come to use English language as a teachingmedium; though they might not be qualified enough to use English as a language of instruction (see the Introduction-type 2). Once more the question is: Would they be the proper instructors to use English as a medium of teaching?
Furthermore, definitely, one could presume that the problem is really there; there is a gap still waiting to be bridged as a controversial matter to specify the fitness of both types of practitioners and the approaches they use to teach ESP. Hence, this study had to select a community of practitioners, and to adopt a sort of model to measure their assumed pedagogical fitness, for carrying out their job as practitioners of ESP, etc.

In his Language Teacher Education for a Global Society, B. Kumaravadivelu (2012) invented a cyclic-modular model whose educational factors, as far as this paper aims at, could be used as parameters to measure the above-mentioned two types academics' comprehensibility of the core principles needed in their profession as pedagogues (see the diagram below whose details will be discussed in a succeeding section), and eventually to judge their educational fitness.

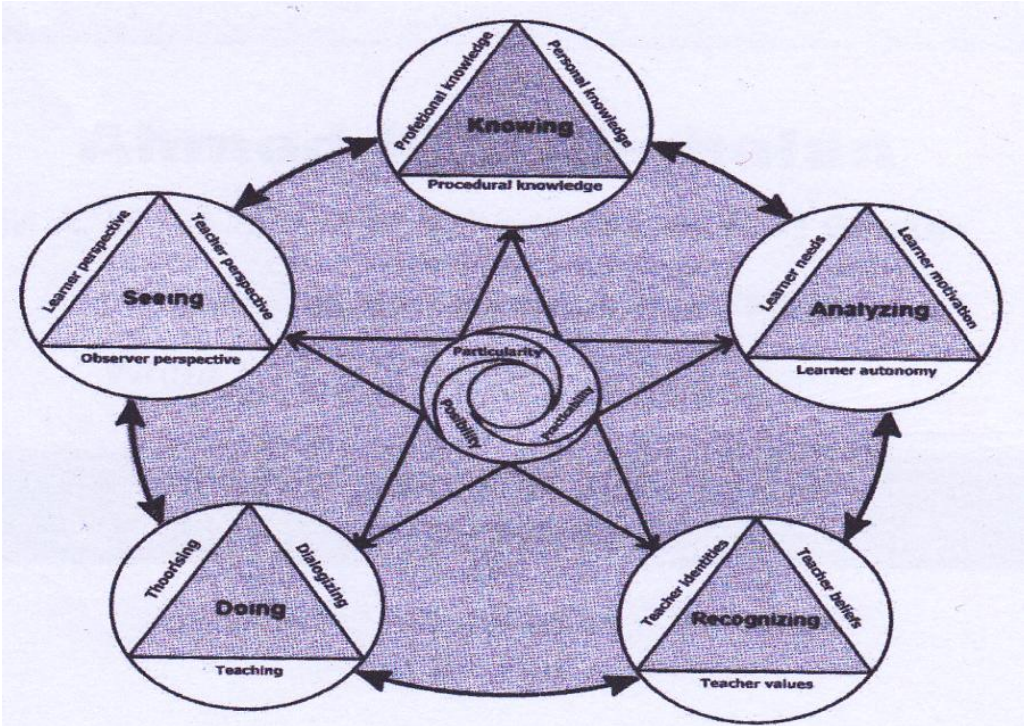

Fig. No.(1):- adopted from Kumaravadivelu's Cyclic-Modular-Model of Progress

\section{Parameters in TEFL (2012)}

\section{3- Aims of the Study}

As far as the investigation of the alreadydiscussed-problem needs, this paper adopted Kumaravadivelu's model (Diagram No.1) as a tool to attempt eliciting some findings about the pedagogical adequacy of approaches used in classroom by two types of practitioners (types $1 \quad \& \quad 2$ ) abovementioned in the Introduction.

So, this study aimed at:
1- Investigating the satisfaction dimension of Kumaravadivelu cyclic-modular-model's parameters by practitioners majored in EFL in their teaching of ESP.

2- Investigating the satisfaction dimension of Kumaravadivelu cyclic-modular-model's parameters by practitioners, majored in scientific branches other than the EFL's, in their teaching of ESP.

\section{4- Hypotheses}


Considering mostly the levels of practitioners' professionalism which might be partly "...because many start teaching before feeling fully competent to do so..." (Senior 2006: 67), it was hypothesized that:

1- EFL-majored-academic-practitioners of ESP, compared to non-EFL-majored academic practitioners, could hardly satisfy the needs of teaching scientific-subject syllabuses other than the EFL syllabuses they majored in.

2- Non-EFL-majored-academic-

practitioners of ESP, compared to the EFLmajored-academic-practitioners, could hardly satisfy the needs of using English as a medium of instruction, depending only on their knowledge about English as a medium of study when they were postgraduatestudents.

\section{5- Significance of the Study}

The importance of the study lies in assumed usefulness of information which would be elicited from the Symposium's academic-attendees, which might eventually be of assistance to identify what kind of practitioner is needed in the ESP classroom, which all would be of a great help to the TEFL community in general, and to the ESP practitioners and researchers, in particular.

\section{6- Limits of the Study}

This two-dimensional study is limited to investigate the pedagogical status of type $1 \&$ 2 (see the Introduction) ESP practitioners (62 in number) who attended the abovementioned Symposium and how far they are stuck to certain educational parameters.

\section{7- Related Literature}

As a matter of fact, since the late-1940s, English has become, among other languages, the dominant global language of science (Montgomery 2013: 57, 107). The more English language has been used as a medium of instruction to teach various new scientificbranches, the more sophisticated and complicated is becoming the rationale and scope of TEFL and related disciplines. This is happening in respect of theorizing both: the purpose for, and the way, of using English as medium of instruction. Hence, apart from the ordinary use of English in disciplines such as TEFL studies, or linguistic studies, or English literature studies, using English as a medium of instruction, all over the world, to teach various scientific branches for various purposes, has attracted an increasing attention from the TEFL field's researchcommunity (Crystal 2012:112). After the rapid spread of terms like ESP, EAP, LSP, CLIL, NDE, etc. demands have emerged to define the basics of ESP, whether in respect of the sort of curriculum needed, the sort of teacher needed, and the sort of methods needed, in order to make the ESP discipline a well-oiled machine (Shalan 2008: 23-28).

$* * * * *$

$* * * * *$

$$
\text { ***** } *
$$

$\boldsymbol{E S P}$ as a notion dates back to 1940 s in the USA, as one of the implications within the applied linguistics rationale, when the linguists needed to apply analytical approaches to develop language-courses for the military. (Rees- Miller- in Arnoff \& Rees Miller 2006:638). Furthermore, still in the USA, the demands emerged to develop socially-normalizing language-courses for the immigrants' purposes (Shalan 2008:10). Then, after the English language spread as a result to the British colonial geographical dominance which started during the $16^{\text {th }}$ century, the bombing of Hiroshima and Nagasaki in 1945 gave the English language a very golden-opportunity to be a dominant global language of science (Crystal 2003: 96115). Thence, a great global attention was paid to the use of English as an EFL, ESL, which in its turn provided the rationale for using English as a medium of instruction mostly all over world. This in its turn provided the opportunity to the breeding ground for the development of various and different related terms such as ESP, EAP, etc., besides tens of sub-terms related to various purposes (for instruction needs, after study perspectives, business management, social normalization, etc.). Furthermore, all that had to do with the use of English as a medium of communication, especially in South-East Asian countries, whose academicinstitutions revolutionized the TEFL, in order to create new approaches to use English as a medium of instruction in particular, and as a means of communication in general. This happend at different levels; curricula design, methods of teaching, and in particular in 
respect of the practitioner's education as an important factor in the progress of using English as a language of instruction (Shalan 2008: 10-30).

Therefore, as part of the curriculum map, some argue that ESP English could be viewed as a separate subject, but with genres related to other scientific-subjects, which in English appears to play a different role and acquiring a further dimension, as a mediumlanguage to teach other subjects. Furthermore, Stevens (1988-cited in Shalan 2008: 23) identifies teacher preparations and special teaching materials, as essentials to the success of TESP.

$$
\begin{gathered}
* * * * \\
* * * * * \\
*
\end{gathered}
$$

Controversially, if being apparently loyal to the traditional Grammar-Translation Approach of TEFL, and most of the EFLmajored practitioners (Type 1- the Introduction) are almost found to insist on their argument that the student, in the ESP classroom, is to be taught a common core English syllabus in which grammar and translation are predominant, rather than specially designed ESP subject-related course. As for the other group (non-EFLmajored ones), the practitioners (Type 2-the Introduction) could be found as having antagonist attitudes to (type 1) practitioners, and even they might go to the extremes as to feeling that type 1 practitioners might be dabbling into an area where they know next to nothing. (Shalan 2008: 21).

Hence, specifying the objectives has become a key demand, because specifying the objectives would definitely indicate what kind of an ESP practitioner is need to meet the said- objectives.

As far as it concerns the teaching of any ESP program, five objectives could be specified by Basturkmen here as follows:

- to reveal subject-specific language,

- to develop target performance competencies,

- $\quad$ to teach underlying knowledge,

- $\quad$ to develop strategic competence, and

- $\quad$ to foster critical awareness.

(Basturkmen 2006: 133)

From Basturkmen one could easily guess that without putting the above-used verbs (reveal, develop, teach, develop, foster) into action no one of those objectives could be achieved, and let alone that an ESP practitioner who should be well-aware of his job. For instance, with implicit reference to the EFL-majored ESP practitioner, Basturkmen borrowed from Early:

"The ESP teacher ... does not in any straightforward sense conform to the image of 'knower'. It is true that he or she possesses specialist knowledge of the target language...; he or she fortunate enough to possess some familiarity with the subject matter relevant to the learner's area of study..."

2006:139)

(Early- cited in Basturkmen

In her Preparing ESP Practitioners for the Unfamiliar, the importance of Carreon's (1996) study lies in the fact that it deals with the dilemma of the non-specialist teacher of the ESP courses. As an ESP practitioner in De La Salle University/Philippines, Edwina S. Carreon significantly admits that:

"...teachers like I, having a background only in literary studies were unable to do very much to modify tasks and exercises to suit our comfort level, for luck of a better understanding of ESP and language teaching principle." (ibid: 8)

Hence, Basturkmen, as though to highlight the role of a genre-specific-practitioner, borrowed from Hyland writing:

"The features of a text ... are influenced by the community for which it was written and so best understood, and taught, through the specific genre of communication."

(Hyland 2002b :41- cited in Basturkmen 2006: 54)

Therefore, the role of the practitioner in the multidimensional ESP phenomenon is still controversial in the context of using English as global language of science, on both sides; the practitioner and the student. On part of the students, the phenomenon is faced with not few problems in respect of how to satisfy the demands of students being taught in their native-language and expected to learn in a language which is not their native one (ibid :620). Meanwhile, on part of the practitioner, the inquiry is about should the ESP practitioner, if not majored in EFL, 'think linguistically' or not (Baily, Beverley, 
\& Freeman, in Spolsky \& Hult -ed. 2008: 611), i.e., “...how teachers come to understand language as an integral element in the content they teach." (ibid: 611). Since ESP teaching approaches are traditionally found to be content-based ones, 'teaching linguistically' might need curricular-designed activities in order to achieve approximation to the curricular content. By contrast: should the EFL-majored-practitioner be qualified, to some extent, in the ESP scientific-branch he is suggested to teach? In his Language for Special purposes: Pedagogy, A. Johns answered the question saying: “... LSP [ESP] teachers and curriculum designers are much more accountable than 'general' language teachers." (Johns;-cited in Spolsky 1999:634). Hence, Johns, furthermore, argued that it is for this reason, good ESP pedagogy should vary from a country to another, from school to another, and from a class to another. As for the practitioner's appropriateness, Johns argued that although teachers who were prepared for linguistics or methods of TEFL are most-likely able to go with a syllabus which is challenging, meanwhile, their colleagues (who were not prepared so) could be found struggling to understand the principles and theoretical framework of using English as a medium of instruction, regardless the approaches they follow to teach an ESP course (Ibid: 634).

As in any ESP classroom, practitioners and students, all over the world, could hardly share a common language for study. Baily, Burkett, and Freeman (Spolsky \& Hult .ed2008:606) argued for 'a double bind can develop'. They explain that "...language of instruction can seem relatively 'transparent' medium through which teaching is done." (ibid: 606) Thus, they explained that though language might still be 'translucent' to students, they could achieve the 'double bind' when they come to learn the language through understanding the genre content. Putting emphasis on the role of the teacher [practitioner], in his Educational Linguistics, James Paul Gee argued that "...specific....languages are acquired via yet more direct and overt instruction." (Gee -in Arnoff \& Rees-Miller -ed. 2006:653). Generally speaking, Gee furthermore emphasized the role of the teacher's approaches to the students explaining that it is the role of the teacher to lead his students to control meta-awareness about the medium of instruction that is fundamental to real understanding of the content. In addition, he argued that when a problem is resided as a 'deficit' inside the student, it is rather a problem resides in the medium of interaction in which the teacher is used, and which might at the same time indicate a lack of necessary educational knowledge to teach the target genre (Gee -in Arnoff \& Rees-Miller -ed. 2006: 663).

In the course of the professional ESP development, the concept of 'genre' has emerged as a distinctive feature of teaching any ESP content. The concept has been highlighted much, in particular, in relation with the most needed two skills of language use: reading and writing (Yoshida 1998; Sinhaneti 1994; Shukor and Others 1993cited in Shalan 2008: 13, 15,18).

To explain the importance of reading and writing as two-strongly connected skills in the ESP courses, and thus, as though to argue that reading as a skill is not any more a completely-passive language skill, and also as though to put the ball in the practitioner's court again, Basturkmen argued for what she calls the Input to Output concepts, which means that the students should be provided with input [reading] which could be used as a basis for production [writing], and she put the failure of the practitioners in this respect as follows: "A common failing in teaching is to expect high level production without giving sufficient input." (Basturkmen 2006: 117), and this, in other words, means that the practitioner should choose specific items as focus of instruction, in order to be presented and highlighted by her/himself. Hence, Johnson \& Johnson highlighted a very important question about the role of the ESP practitioners if they should specialize, or not, in the subjects or professions of their learners, or even be practitioners in those areas and only subsequently trained in ELT or ESP." (Johnson \& Johnson 1999: 109).

Assuming that most of the ESP practitioners, whether EFL-majored or other subjectsmajored, are assumingly good as pedagogues, but still the difference between a good teacher and a great teacher, as Senior 
2006: 74) put it, is that " $\ldots$ a great teacher was one who constantly strove for excellence."

How can excellent teaching be realized?

In his Language Teachers Education for Global Society: A Modular Model for Knowing, Analyzing, Recognizing, Doing and Seeing (see Figure No.1), B. Kumaravadivelu (2012) created a model which can be adopted, for the purpose of this study, as scale to investigate how far the ESP practitioners attained the presumed excellency in their teaching within the frame of English as a Global language of science.

As it is seen in Figure No.1, in the core of the model three parameters are proposed to functionally-operate as spiral principles for the pedagogue's education, and to offer "a pattern that connects the role of learners, teachers, and teacher educators" (Kumaravadivelu 2001: 557- cited in Kumaravadivelu 2012: 12). To summarize, these three principles are:

1- Particularity: This, in brief, means that pedagogy must be constructed on a holistic interpretation of particular situations.

2- Practicality: Which broadly means connecting theory to practice, and narrowly means the teacher's skill to monitor their pedagogy effectiveness.

3- Possibility: It refers to favoring the education programs that raise sociopolitical consciousness to meet the quest of subjectivity and self-identity (Chris Weeden 2997: 21- cited in Kumaravadivelu 2012: 15).

Furthermore, the peripheral vision of the model can show five spiral-triangular modules, each with three parameters connected via an assumed dynamic means to the three core spiral-principles, which the practitioner should pay attention to:

1- Knowing: The emphasis here is more on the ways of practitioner's knowing, as an action, than on the body of knowledge; to realize her/his:

- Professional Knowledge as received wisdom from experts who are engaged in knowledge production on teaching in a given discipline.
- Procedural Knowledge which is about facilitating the flow of the lesson and guiding it in the right direction.

- Personal Knowledge which signifies the pedagogue's thought processes through observations, experiences, and education programs.

(ibid: 20-36)

2- Analyzing: This means that the practitioner should develop procedures to analyze and understand the following:

- Learner Needs which represents the gap between what is and what should be (Brindley 1984- cited in Kumaravadivelu 2012: 38)

- Learner Motivation whether instrumental or integrative have constant and meaningful effects on learning and on behavioral indices of learning (Gardener \& Maclntyre 1991: 69- cited in Kumaravadivelu 2012: 41).

- Learner Autonomy: With reference to the concept of 'learn to learn', it is defined as "the ability to take charge of one's own learning" (Holec 1981: 3- cited in Kumaravadivelu 2012: 46).

(Kumaravadivelu 2012: 37-54)

3- Recognizing: This means using recognition to identify the teaching Self as it depends largely on the practitioner's awareness of:

- Teacher Identities: Recognizing the teacher identities as constructed ones at the complex intersections between individual, social, national, and global realities.

- Teacher Beliefs: Recognizing how the practitioner's beliefs shape the educational dispositions and decision-making on the part of present and prospective teachers.

- Teacher Values: Recognizing that "values education.....encourages reflections on choices, exploration of opportunities and commitment to responsibilities,..." (Taylor 1994: 3- cited in Kumaravadivelu 2012: 65)

(Kumaravadivelu 2012: 55-77)

4- Doing: It relates to the act of the following:

- Teaching: This means doing the act of teaching as though to maximize the "appropriate learning opportunities to reach the intended learning goals" (David Crabbe 2003: 31-cited in Kumaravadivelu 2012: 80), 
and to monitor the students' personal transformation in the way they "understand themselves, their social surroundings, their histories, and their possibilities for the future,..." (Norton \& Toohey 2004: 1- cited in Kumaravadivelu 2012: 83).

- Theorizing: This relates to the increasing of the practitioner's "awareness of why it is that they teach the way they do, along with the commitment to improving their ability to articulate that awareness,..." (Julian Edge 2001: 653- cited in Kumaravadivelu 2012: 84).

- Dialogizing: This has to do with “...a stance toward experiences and ideas- a willingness to wonder, to ask questions, to seek to understand by collaborating with others in the attempt to make answers to them..." (Wells 1999: 121- cited in Kumaravadivelu 2012: 93).

(Kumaravadivelu 2012: 78-98)

5- Seeing: It relates "...to see-as and do-as that allows us to have a feel for problems that do not fit existing rules." Schon 1983- cited in Kumaravadivelu 2000:361- recited in Kumaravadivelu 2012: 100), in order to realize seeing concept the following points should be born in mind:

- Learners Perspectives: This refers to the “...medium through which we may better understand both the process and the outcomes of learner participation" (Michael Breen 2001: 129-cited in Kumaravadivelu 2012: 103), as a negotiator, problem-solver, builder, investor, and struggler.

- Teacher perspectives: This refers to the practitioners' attempts to "...ensure that the social atmosphere of the classroom is neither too serious nor too light-hearted, neither too heavy nor too frothy-sensing that the balance between these two extremes is desirable." Farrell 2006: 272- cited in Kumaravadivelu 2012: 106).

- Observer perspectives: It is believed that “... peer observation offers opportunities for practicing teachers to monitor and evaluate their own teaching acts with the help of their colleagues..." (Kumaravadivelu 2012: 109).

(Kumaravadivelu 2012: 99-121)

Significantly, it is worth-mentioning that in naming the modules and their subtriangular-parameters, Kumaravadivelu used the -ing-gerund form instead of the related noun form (e.g. knowing instead of knowledge, recognizing instead of recognition, etc.), this is, which makes the parameters more powerful and dynamic in action on part of the practitioner.

Finally, in his Learning Teaching: The Essential Guide to English Language Teaching, Jim Scrivener pedagogically put it this way:

"ESP contrasts with the rather mischievous acronym TENOR (Teaching English for No Obvious Reason); it implies that we are going to take the client's needs and goals more seriously when planning the course the course,..., to tailor everything to his or her character and particular requirements." (Scrivener 2011:310)

In their Language Teaching and Learning in the Postlinguistic Condition, Nelson and Kern borrowed from Kumaravadivelu (1994):

"Post-method condition empowers practitioners to construct classroom-oriented theories of practice .... [and] enables practitioners to generate location-specific, classroom-oriented innovative practices."

(Kumaravadivelu 1994: 28-29, Nelson \& Kern, in Asagoff, Mckay, $\mathrm{Hu}$, and Renandya -ed. 2012: 47-48)

\section{8- Definitions of Basic Terms}

1- ESP English for Specific (Special) Purposes: The English used for various purposes (immigrants' normalization in new communities, academic instruction, business administration, social communication, etc.) (Richard \& Schmidt 2002:186)

2- EAP English for Academic Purposes: The English used as medium of instruction in schools, universities, and other academic institutions to teach scientific-branches other than the linguistic scientific-branches. (Richard \& Schmidt 2002:173)

3- CLIL Content \& Language Integrative Learning: A European term dating back to 1994, and refers to teaching content through a language other than the first language of the learners, which eventually indicates using English to learn subject content. (Scrivener 2011: 327)

4- Genre: A term used to refer to the types of 'text' as distinguished by their function or 
their form (Mattews 2007: 157; Harmer 2011:327)

5- $\boldsymbol{L S P}$ Language for Special Purposes: This term is derived from the concept of 'specificity', i.e., "each pedagogical situation and each group of learners is considered to be new and different" (Johns- ed. in Spolsky 1999: 633

6- $N D E$ Non-Departmental English: A locally-invented term, among the Iraqi academic institutions, which mostly-like stands for a function like that of the $\boldsymbol{E A P}$.

7- Practitioner: A term used to refer to the instructor who practices teaching $\boldsymbol{E S P}$ (Shalan 2008: 23-4)

\section{9- PROCEDURES:}

\section{9-1 Population \& Questionnaire}

The said Symposium's attending practitioners as whole were taken as a population of the study.

In favor of the questionnaire as a procedure to elicit benefits from discussions carried out in a situation like the said Symposium's event, Harmer argued that:

"Questionnaires are useful because, by being pre-planned, they ensure that both questioners and respondents have something to say to each other." (Harmer 2007: 352)

Hence, the dimensions (a core one plus 5 peripheral dimension as seen in the Table No.1) of Kumaravadivelu modular model's parameters (grouped in three parameters for each dimension) were used as the questionnaire's statement-items, and were designed to best-suit the status of the twotypes of the said Symposium's academic attendees (see the Introduction) as follows:

1- A questionnaire form to address the attending practitioners type 1 (27 attendees).

2- A questionnaire form to address the attending practitioners type 2 (attendees).

The two types of questionnaire forms were distributed during the Symposium's event to elicit any information about the ESP attending practitioner (Practs. henceforth) educational-fitness in using English as a medium of instruction. The feeding-back questionnaire forms were given back as follows:

- For type 1 only 19 out of 27 , and

- For type 2 only 23 out of 31.

Data Statistical Analysis

Table No.(1): -Practitioners' Responses to Dimension 1

\begin{tabular}{|c|c|c|c|c|c|c|c|c|}
\hline \multirow[t]{2}{*}{ Item } & \multirow[t]{2}{*}{ Group } & \multicolumn{5}{|c|}{ Response } & \multirow{2}{*}{$\begin{array}{c}\text { Chi- } \\
\text { square }\end{array}$} & \multirow[t]{2}{*}{ Sig. } \\
\hline & & Never & Rarely & Sometimes & Often & Always & & \\
\hline \multirow[t]{2}{*}{1} & EFL Pra. & 1 & 1 & 3 & 9 & 9 & $3.083^{\mathrm{a}}$ & N.S \\
\hline & $\begin{array}{c}\text { Non-EFL } \\
\text { Pra }\end{array}$ & 1 & 0 & 8 & 10 & 4 & & \\
\hline \multirow[t]{2}{*}{2} & EFL Pra. & 0 & 4 & 8 & 3 & 4 & $11.799^{\mathrm{a}}$ & 0.05 \\
\hline & $\begin{array}{c}\text { Non-EFL } \\
\text { Pra. }\end{array}$ & 0 & 1 & 3 & 15 & 4 & & \\
\hline \multirow[t]{2}{*}{3} & EFL Pra. & 0 & 2 & 3 & 10 & 4 & $3.917^{\mathrm{a}}$ & N.S \\
\hline & $\begin{array}{c}\text { Non-EFL } \\
\text { Pra. }\end{array}$ & 0 & 1 & 9 & 7 & 6 & & \\
\hline
\end{tabular}

Table No(.2):- Practitioners' Responses to Dimension 2

\begin{tabular}{|c|c|c|c|c|c|c|c|c|}
\hline \multirow[t]{2}{*}{ Item } & \multirow[t]{2}{*}{ Group } & \multicolumn{5}{|c|}{ Response } & \multirow{2}{*}{$\begin{array}{l}\text { Chi- } \\
\text { square }\end{array}$} & \multirow[t]{2}{*}{ Sig. } \\
\hline & & Never & Rarely & Sometimes & Often & Always & & \\
\hline \multirow[t]{2}{*}{1} & EFL Pra. & 0 & 3 & 5 & 9 & 2 & $2.177^{\mathrm{a}}$ & N.S \\
\hline & Non-EFL Pra & 1 & 2 & 5 & 10 & 5 & & \\
\hline \multirow[t]{2}{*}{2} & EFL Pra. & 1 & 3 & 6 & 6 & 3 & $6.276^{\mathrm{a}}$ & N.S \\
\hline & $\begin{array}{c}\text { Non-EFL } \\
\text { Pra. }\end{array}$ & 0 & 1 & 3 & 12 & 7 & & \\
\hline \multirow[t]{2}{*}{3} & EFL Pra. & 0 & 2 & 9 & 7 & 1 & $9.416^{\mathrm{a}}$ & .052 \\
\hline & $\begin{array}{c}\text { Non-EFL } \\
\text { Pra. }\end{array}$ & 1 & 3 & 3 & 8 & 8 & & \\
\hline
\end{tabular}


Table No.(3):- Practitioners' Responses to Dimension 3

\begin{tabular}{|c|c|c|c|c|c|c|c|c|}
\hline \multirow[t]{2}{*}{ Item } & \multirow[t]{2}{*}{ Group } & \multicolumn{5}{|c|}{ Response } & \multirow{2}{*}{$\begin{array}{c}\text { Chi- } \\
\text { square }\end{array}$} & \multirow[t]{2}{*}{ Sig. } \\
\hline & & Never & Rarely & Sometimes & Often & Always & & \\
\hline \multirow[t]{2}{*}{1} & EFL Pra. & 1 & 3 & 4 & 7 & 4 & \multirow[t]{2}{*}{$6.470^{\mathrm{a}}$} & \multirow[t]{2}{*}{ N.S } \\
\hline & Non-EFL Pra & 0 & 0 & 3 & 12 & 8 & & \\
\hline \multirow[t]{2}{*}{2} & EFL Pra. & 2 & 3 & 7 & 3 & 4 & \multirow[t]{2}{*}{$8.670^{a}$} & \multirow[t]{2}{*}{ N.S } \\
\hline & $\begin{array}{c}\text { Non-EFL } \\
\text { Pra. }\end{array}$ & 4 & 2 & 1 & 8 & 8 & & \\
\hline \multirow[t]{2}{*}{3} & EFL Pra. & 0 & 1 & 6 & 6 & 6 & \multirow[t]{2}{*}{$3.138^{a}$} & \multirow[t]{2}{*}{.535} \\
\hline & $\begin{array}{c}\text { Non-EFL } \\
\text { Pra. }\end{array}$ & 1 & 3 & 10 & 4 & 5 & & \\
\hline
\end{tabular}

Table No.(4):- Practitioners' Responses to Dimension 4

\begin{tabular}{|c|c|c|c|c|c|c|c|c|}
\hline \multirow[t]{2}{*}{ Item } & \multirow[t]{2}{*}{ Group } & \multicolumn{5}{|c|}{ Response } & \multirow{2}{*}{$\begin{array}{c}\text { Chi- } \\
\text { square }\end{array}$} & \multirow[t]{2}{*}{ Sig. } \\
\hline & & Never & Rarely & Sometimes & Often & Always & & \\
\hline \multirow[t]{2}{*}{1} & EFL Pra. & 0 & 1 & 4 & 9 & 5 & $3.657^{a}$ & N.S \\
\hline & $\begin{array}{c}\text { Non-EFL } \\
\text { Pra }\end{array}$ & 1 & 5 & 5 & 10 & 2 & & \\
\hline \multirow[t]{2}{*}{2} & EFL Pra. & 1 & 3 & 8 & 3 & 4 & $2.299^{\mathrm{a}}$ & N.S \\
\hline & $\begin{array}{c}\text { Non-EFL } \\
\text { Pra. }\end{array}$ & 0 & 2 & 9 & 6 & 6 & & \\
\hline \multirow[t]{2}{*}{3} & EFL Pra. & 1 & 2 & 7 & 5 & 4 & $2.703^{a}$ & N.S \\
\hline & $\begin{array}{c}\text { Non-EFL } \\
\text { Pra. }\end{array}$ & 0 & 1 & 9 & 10 & 7 & & \\
\hline
\end{tabular}

Table No.(5):- Practitioners' Responses to Dimension 5

\begin{tabular}{|c|c|c|c|c|c|c|c|c|}
\hline \multirow[t]{2}{*}{ Item } & \multirow[t]{2}{*}{ Group } & \multicolumn{5}{|c|}{ Response } & \multirow{2}{*}{$\begin{array}{c}\text { Chi- } \\
\text { square }\end{array}$} & \multirow[t]{2}{*}{ Sig. } \\
\hline & & Never & Rarely & Sometimes & Often & Always & & \\
\hline \multirow[t]{2}{*}{1} & EFL Pra. & 0 & 4 & 4 & 7 & 4 & \multirow[t]{2}{*}{$3.819^{a}$} & \multirow[t]{2}{*}{ N.S } \\
\hline & Non-EFL Pra & 0 & 1 & 8 & 11 & 3 & & \\
\hline \multirow[t]{2}{*}{2} & EFL Pra. & 0 & 4 & 5 & 4 & 6 & \multirow[t]{2}{*}{$6.387^{a}$} & \multirow[t]{2}{*}{ N.S } \\
\hline & Non-EFL Pra. & 1 & 0 & 6 & 8 & 8 & & \\
\hline \multirow[t]{2}{*}{3} & EFL Pra. & 0 & 1 & 7 & 4 & 7 & \multirow[t]{2}{*}{$6.680^{\mathrm{a}}$} & \multirow[t]{2}{*}{ N.S } \\
\hline & Non-EFL Pra. & 0 & 4 & 3 & 11 & 5 & & \\
\hline
\end{tabular}

Table No.(6):- Practitioners' Responses to Dimension 6

\begin{tabular}{|c|c|c|c|c|c|c|c|c|}
\hline \multirow[t]{2}{*}{ Item } & \multirow[t]{2}{*}{ Group } & & & & \multicolumn{2}{|c|}{ Response } & \multirow{2}{*}{$\begin{array}{l}\text { Chi- } \\
\text { square }\end{array}$} & \multirow[t]{2}{*}{ Sig. } \\
\hline & & Never & Rarely & Sometimes & Often & Always & & \\
\hline \multirow[t]{2}{*}{1} & EFL Pra. & 2 & 0 & 8 & 7 & 2 & $5.987 a$ & N.S \\
\hline & Non-EFL Pra & 0 & 1 & 6 & 9 & 7 & & \\
\hline \multirow[t]{2}{*}{2} & EFL Pra. & 0 & 3 & 6 & 8 & 2 & $1.229 a$ & N.S \\
\hline & Non-EFL Pra. & 0 & 3 & 5 & 10 & 5 & & \\
\hline \multirow[t]{2}{*}{3} & EFL Pra. & 0 & 3 & 5 & 6 & 5 & $2.142 a$ & N.S \\
\hline & Non-EFL Pra. & 0 & 2 & 7 & 11 & 3 & & \\
\hline
\end{tabular}

Using the Chi-square program to analyze the responses of the two types of ESP practitioners, analyzing the data gained, and then surveying the results of the statistical analysis in table No. 1, 2, 3, 4, 5, and 6, only in two dimensions significant differences could be seen between the performances of the two types of ESP practitioners (Type 11 nd 2), in favor of type 2 practitioners; satisfying the objectives of the parameters given in the six dimensions of Kumaravadivelu's cyclic module model (Figure No. 1) as follow:

- Dimension 1 (Operating Principles)/ parameter 2 (Particularity): The significant difference is seen of (.050) degree between the performances of the two types of practitioners in favor of (type 2).

- Dimension 2 (Knowing)/ parameter 3 (Procedural Knowledge): The significant difference is seen of (.050) degree between the performances of the two types of practitioners in favor of (type 2).

\section{9-2 Further Comments}

As for the further comments presumed to be given by the questioned practitioners as part of the questionnaire, only two practitioners gave further comments as follows: 
1- (Type 1 practitioner/CoL-NzU): "I believe that the whole system of instruction, from $A$ to $Z$, is in a mess. A comprehensive plan for the region is unavailable."

2- (Type 2 practitioner/CoAE-NzU): "The form of the questions might not be clear enough for some participants."

3-

\section{0-CONCLUSIONS AND RECOMMENDATIONS}

\section{0-1 Conclusions}

Analyzing the results gave rise to the following conclusions:

1- Responses of both two types of ESP practitioners, EFL-majored-practitioners and non-EFL-majored-practitioners, could fairly respond to Kumaravadivelu model's parameters, and thus seemed to be satisfying modestly the pedagogical principles of teaching ESP programs, though with the required minimum.

2- Type 2 (non-EFL-majored-practitioners) seemed to respond better than type 1 (EFLmajored-practitioners), at least in two dimensions of Kumaravadivelu cyclic model's parameters. This can be reasoned out and justified by declaring that the non-EFLmajored practitioners worked in their very field of knowledge; in addition, they could acquire experience in using English as a medium of instruction while they were postgraduate-students, which made them aware enough of how to address their students in English.

3- The further comment coming from a practitioner/CoL-NzU (see section 9-3) has figured out a very important fact about the absence of a national plan for the ESP discipline, which can be achieved only by collaboration between the major academic institutions in Kurdistan Region.

4- The further comment coming from a practitioner/CoAE-NzU (see section 9-3) has figured out another important fact about the gap in the non-EFL-majored-practitioners' knowledge about the register used in the EFL discipline community, which could be bridged by giving type-2-practitioners training courses on how to use English as medium of instruction..

\section{0-2 Recommendations}

The topics which were at issue on the above-mentioned Symposium's table of discussion have uncovered the so many problems coming across the teaching of ESP programs in general. The discussions marked in particular the need to recommend the following:

1- A national plan of an educational ESP network summarizes the needs and the goals of the ESP discipline as in the diagram below: 


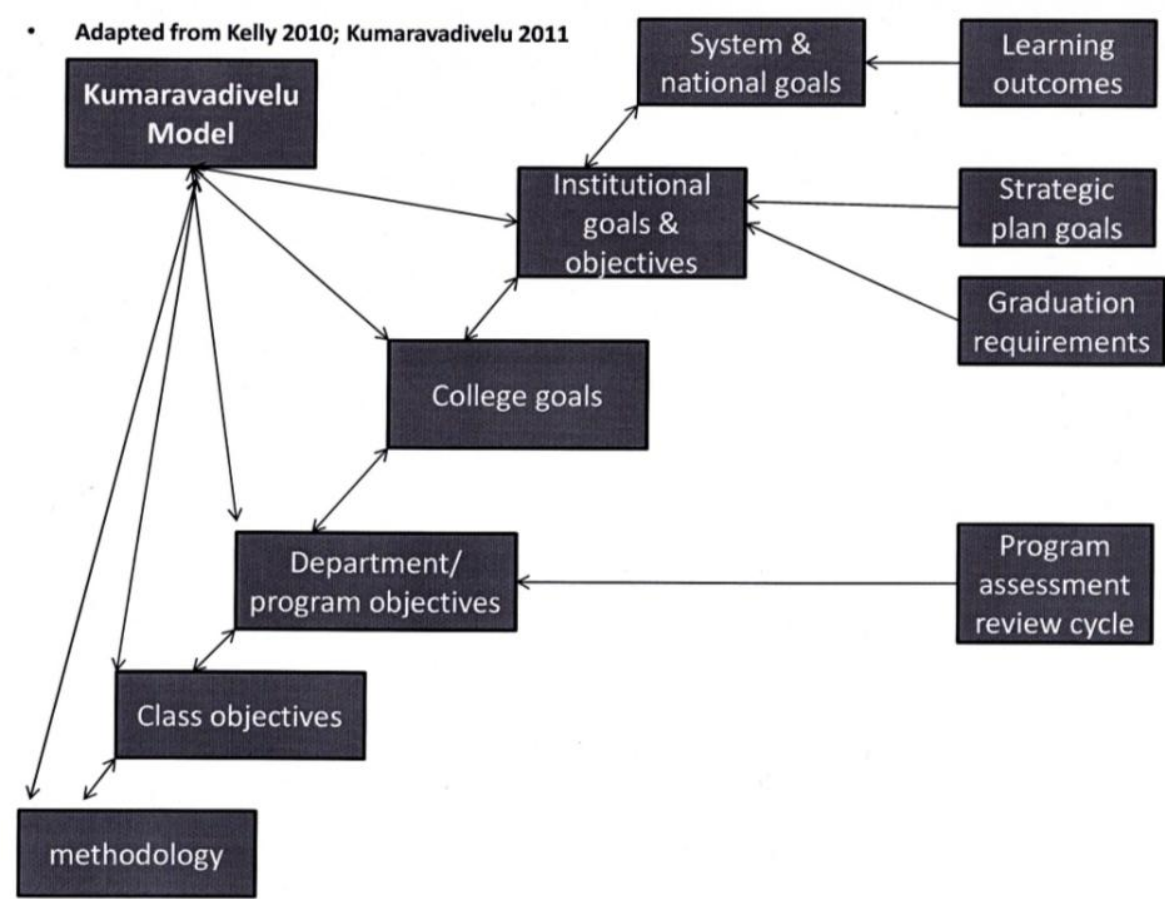

Fig. No.( 2):- ESP Network Plan Summarizes ESP Discipline Goals

2- The need to develop a specialized ESP unit in every university's department of Scientific Development \& Training to be responsible of reviewing and renewing, at least every-other-year, the ESP programs design of every scientific department.

\section{REFERENCES}

- Alsagoff, Lubna \& Mackay, Sandra Lee \& Hu, Guangwei \& Renandya, Willy A. (2012) edited. Principles and practices for Teaching English as an International Language. Routledge USA \& UK

- Aronoff, Mark \& Rees-Miller, Janie (2006) edited. Handbook of Linguistics. Blackwell Publishing. USA \& UK

- Basturkmen, Helen (2006) Ideas and Options in English for Specific Purposes. Lawrence Erlbaum Associates Inc. New Jersey. USA

- Branden,Kris Van den (2006) edited. TaskBased Language Education. Cambridge Applied Linguistics. UK \& New York

- Carreon, Edwina; Balarbar Corazon V. (1997), A Paradigm for ESP Materials Preparation- a research paper presented at the Annual Meeting of the Teachers of English as a Second or Other Language (the Ohio State Univ. Columbus 1997), Dela Salle Univ. Manila/Philippines.
- Crystal, David (2012) English as a Global Language. Cambridge University Press. UK

- Crystal, David (2003) THE CAMBRIDGE ENCYCLOPEDIA OF THE ENGLISH LANGUAGE. Cambridge University Press. UK

- Harmer, Jeremy (2007) The Practice of Teaching English Language. Pearson: Longman. UK

- Hedge, Tricia (2003) Teaching and Learning in the Second language Classroom. Oxford University Press. UK

- AT THE COLLEGES OF PHYSICAL EDUCATION' AND SUGGESTING AN UP-TO-DATE ONE. MA theses. University of Diyala. Baqubah. Iraq

- Senior, Rose M. (2006) The Experience of language Teaching. Cambridge University Press. UK

- Spolsky, Bernard \& Hult, Francis M. (2008) edited. The handbook of Educational Linguistics. Blackwell Publishers. UK

- Spolsky, Bernard (1999) edited. CONCISE ENCYCLOPEDIA OF EDUCATIONAL LINGUISTICS. Elsevier Science Ltd. Oxford

- Widdowson, H. G. (2003) Defining Issues in English language Teaching. Oxford. UK 


\section{App. I}

\section{APPENDIXES}

Names of the Jur

y who examined the questionnaire forms:

1- Dr. Hussein Ali Gargari (Prof.)/ College of Languages/ Nawroz University

2- Dr. Chachaan Jum'ah Mohammed (Assist Prof.)/Department of Psychological \& Educational Sciences /Faculty of Basic education/University of Duhok

3- Dr. Sami Abdul-Aziz Al-Ma'mouri (Prof.)/Department of English/College of Basic Education/ University of Diyala.

App. II A

Questionnaire (sample 1: for the symposium's attendees type 1)

Dear Sir (Madam)

The researcher is carrying out a research paper, “'Investigating The TEFL/ESP Practitioner's Dilemmatic Current Status in the Iraqi Kurdistan Region", as a two-dimensional research-work.

This questionnaire is one of the dimensions of the research-paper.

In the context of Teaching English as a Foreign Language TEFL/ESP, in his Language Teacher Education for a Global Society, B. Kumaravadivelu (2012) speculates a cyclic-modular model with certain parameters (see the diagram below) that could be used by the teachers to make self-assessment of their performance in the classroom when using English as a medium of instruction.

\section{Facsimile of Figure No. 1}

The questionnaire items below are derived from B. Kumaravadivelu's parameters.

Attending the Symposium of 'Teaching ESP in Kurdistan: Reality and Perspectives', and taking part in the discussions, in order to assess how successful you have been in so far as considering the said Kumaravadivelu's presumed-parameters, in the light of the competence you have, as a specialist in $E F L$ and at the same time as a practitioner you teach in what in terms of applied linguistics is called either English for Specific Purposes ESP, or English for Academic Purposes EAP, or NonDepartmental English NDE, or Content and Language Integrative Learning CLIL, please give your frank and sincere answers to the questionnaire-statements.

Expecting your cooperation, please accept our best regards.

Researcher Researcher

Nawroz University University of Zakho

\begin{tabular}{l}
\hline University: \\
\hline College: \\
\hline Specialization: \\
\hline Scientific degree \& title: \\
\hline Department of instruction: \\
\hline Language of instruction when you were at college-study: \\
\hline Language of instruction now as a teacher: \\
\hline
\end{tabular}




\begin{tabular}{|c|c|c|c|c|c|c|}
\hline No. & Statements & Always & Often & Sometimes & Rarely & Never \\
\hline & $\begin{array}{l}\text { OPERATING PRINCIPLE of using } \\
\text { English as a medium of instruction. }\end{array}$ & & & Dimension 1 & & \\
\hline 1 & $\begin{array}{l}\text { Principle of PARTICULARITY: Teachers } \\
\text { education programs in English must be } \\
\text { sensitive to a particular group of learners. }\end{array}$ & & & & & \\
\hline 2 & $\begin{array}{l}\text { Principle of PARTICULARITY: Maximizing } \\
\text { learning opportunities in English in the } \\
\text { classroom and transforming the learners' } \\
\text { possibilities in and outside the classroom. }\end{array}$ & & & & & \\
\hline \multirow[t]{2}{*}{3} & $\begin{array}{l}\text { Principle of POSSIBILITY: Pedagogy } \\
\text { empowers the students to critically } \\
\text { appropriate form of knowledge outside } \\
\text { of their immediate experience. }\end{array}$ & & & & & \\
\hline & $\begin{array}{l}\text { KNOWING: The emphasis is on the } \\
\text { ways of knowing than on the body of } \\
\text { knowledge }\end{array}$ & & & Dimension 2 & & \\
\hline 4 & $\begin{array}{l}\text { Knowing PROFESSIONAL } \\
\text { KNOWLEDGE: The intellectual content of } \\
\text { the discipline, a compilation of facts, } \\
\text { theories, and concepts. }\end{array}$ & & & & & \\
\hline 5 & $\begin{array}{l}\text { Knowing KNOWLEDGE ABOUT } \\
\text { LANGUAGE: Language as a system, } \\
\text { language as a discourse, and language as } \\
\text { an ideology, i.e., knowledge about } \\
\text { learning and teaching }\end{array}$ & & & & & \\
\hline \multirow[t]{2}{*}{6} & $\begin{array}{l}\text { Knowing PROCEDURAL KNOWLEDGE } \\
\text { (personal knowledge): Facilitating the } \\
\text { flow of the lesson and channelizing it in } \\
\text { the right direction, i.e., the action teachers } \\
\text { take to create an environment that } \\
\text { supports and facilitates both academic } \\
\text { and socio-emotional learning. }\end{array}$ & & & & & \\
\hline & $\begin{array}{l}\text { ANALYZING: Developing the } \\
\text { knowledge and skill necessary to } \\
\text { analyze }\end{array}$ & & & Dimension 3 & & \\
\hline 7 & $\begin{array}{l}\text { Analyzing the LEARNER's NEEDS which } \\
\text { states the gap between what is and what } \\
\text { should be. }\end{array}$ & & & & & \\
\hline 8 & $\begin{array}{l}\text { Analyzing the learner's motivation, } \\
\text { i.e., one's belief in the ability to } \\
\text { influence and accomplish desired } \\
\text { outcomes. }\end{array}$ & & & & & \\
\hline \multirow[t]{2}{*}{9} & $\begin{array}{l}\text { Analyzing the LEARNER's AUTONOMY, } \\
\text { i.e., the ability to take charge of one's own } \\
\text { learning by self-regulation for learning } \\
\text { academic performance and wellbeing, }\end{array}$ & & & & & \\
\hline & $\begin{array}{l}\text { RECOGNIZING: Recognizing depends on } \\
\text { the teaching SELF. }\end{array}$ & & & Dimension 4 & & \\
\hline 10 & $\begin{array}{l}\text { Recognizing the TEACHER IDENTITY, by } \\
\text { concept, and not marked by passivity and } \\
\text { conformity but by socially engendered } \\
\text { reactivity. }\end{array}$ & & & & & \\
\hline 11 & $\begin{array}{l}\text { Recognizing the TEACHER's BELIEFS, } \\
\text { i.e., the construct of beliefs and } \\
\text { dispositions when using English as a } \\
\text { medium of instruction. }\end{array}$ & & & & & \\
\hline \multirow[t]{2}{*}{12} & $\begin{array}{l}\text { Recognizing the TEACHER's VALUES, } \\
\text { i.e., the standards of professional morals } \\
\text { must be high within an appropriate social } \\
\text { environment, by continually interrogating } \\
\text { the teaching SELF }\end{array}$ & & & & & \\
\hline & $\begin{array}{l}\text { DOING: It means there need not to be } \\
\text { a 'doer behind the deed', but that the } \\
\text { 'doer' is variably constructed in and } \\
\text { through the deed. }\end{array}$ & & & Dimension 5 & & \\
\hline 13 & $\begin{array}{l}\text { Doing } \text { TEACHING as an intellectual } \\
\text { activity grounded in reflective thought } \\
\text { processes involving creativity, artistry. }\end{array}$ & & & & & \\
\hline
\end{tabular}




\begin{tabular}{|c|c|c|}
\hline & $\begin{array}{l}\text { and context-sensitivity. Furthermore, } \\
\text { maximizing learning opportunities and } \\
\text { mentoring personal transformation. }\end{array}$ & \\
\hline 14 & $\begin{array}{l}\text { Doing THEORIZING which means in } \\
\text { addition to the professional theory of } \\
\text { education, the teacher should develop } \\
\text { their personal theory, in order to } \\
\text { identify problems and prospects of } \\
\text { learning under methodological } \\
\text { considerations. }\end{array}$ & \\
\hline \multirow[t]{2}{*}{15} & $\begin{array}{l}\text { Doing DIALOGIZING which means } \\
\text { the teacher inquiry is dialogic inquiry } \\
\text { aiming not at 'knowing-for-the-sake- } \\
\text { of-knowing, but learning to develop } \\
\text { the disposition and ability to act } \\
\text { informedly and responsibly. }\end{array}$ & \\
\hline & $\begin{array}{l}\text { SEEING 'The question is not what you } \\
\text { look at but what you see.' (Thoreau } \\
\text { 1851) }\end{array}$ & Dimension 6 \\
\hline 16 & $\begin{array}{l}\text { Seeing LEARNER PERSPECTIVE } \\
\text { which means on-going self-evaluation } \\
\text { the students undertake to monitor and } \\
\text { assess the progress they make in } \\
\text { carrying out the activity they } \\
\text { undertake. }\end{array}$ & \\
\hline 17 & $\begin{array}{l}\text { Seeing TEACHER PERSPECTIVE } \\
\text { which means the teacher's control of } \\
\text { everything happens in the classroom, } \\
\text { i.e., teacher as a vendor, teacher as } \\
\text { entertainer, and teacher as } \\
\text { communication controller. }\end{array}$ & \\
\hline 18 & $\begin{array}{l}\text { Seeing OBSERVER PERSPECTIVE } \\
\text { which means a purposeful and } \\
\text { periodical dialogue with observing and } \\
\text { observant person to examine the } \\
\text { pedagogical principles and practices. }\end{array}$ & \\
\hline
\end{tabular}

Any further comments:

\section{App. II B}

Questionnaire (sample 2: for the Symposium's attendees type 2)

Dear Sir (Madam)

The researcher is carrying out a research paper, "Investigating The TEFL/ESP Practitioner's Dilemmatic Status in the Iraqi Kurdistan Region", as a two-dimensional research-work.

This questionnaire is one of the dimensions of the research-paper.

In the context of Teaching English as a Foreign Language TEFL/ESP, in his Language Teacher Education for a Global Society, B. Kumaravadivelu (2012) speculates cyclic-modular model with certain parameters (see the diagram below) that could be used by the teachers to make self-assessment of their performance in TEFL, i.e., when using English as a medium.

Facsimile of Figure No. 1

The questionnaire items below are derived from B. Kumaravadivelu's parameters.

Attending the Symposium of 'Teaching ESP in Kurdistan: Reality and Perspectives', and taking part in the discussions, in order to assess how successful you have been in so far as considering the said Kumaravadivelu's presumed parameters, in the light of the competence you have, as a non-specialist in the English Language sciences but as a practitioner you teach the materials of your scientific-major in what, in terms of applied linguistics, is called either English for Specific Purposes ESP or English for Academic Purposes EAP, or Non-Departmental English NDE, or Content and Language Integrated Learning CLIL, please give your frank and sincere answers to the questionnaire-statements.

Expecting your cooperation, please accept our best regards.

Researcher

Nawroz University

Researcher

University of Zakho 
Journal of University of Duhok., Vol. 20, No.2 (Humanities. and Social. Sciences), Pp 51-67, 2017 elSSN: 2521-4861 \& pISSN: $1812-7568$

https://doi.org/10.26682/hjuod.2017.20.2.5

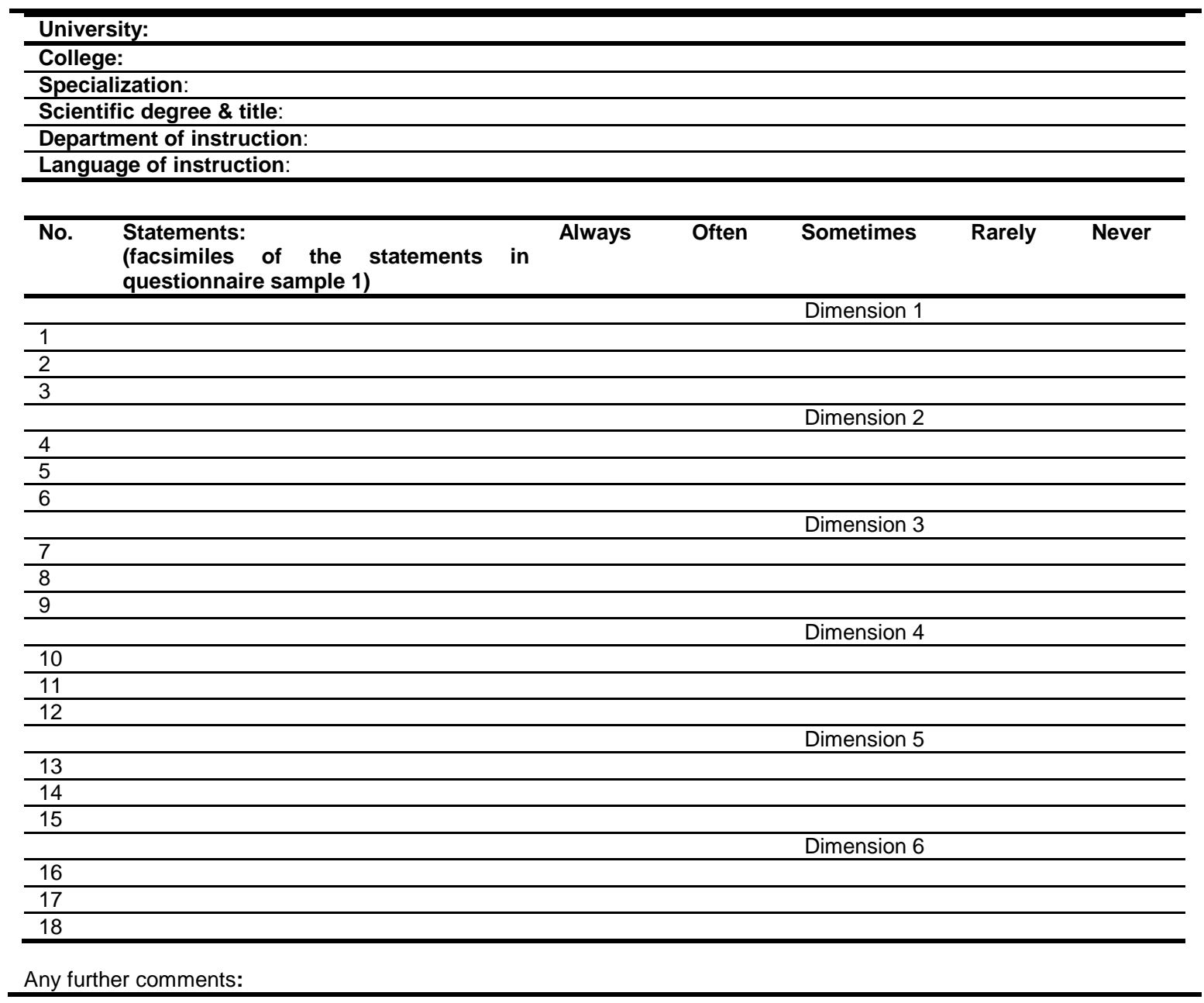


الخلاصة

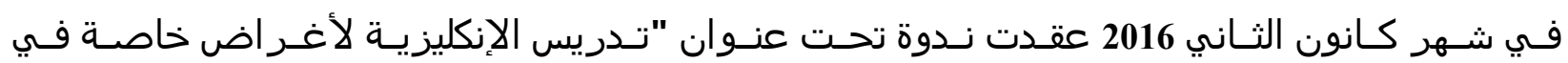

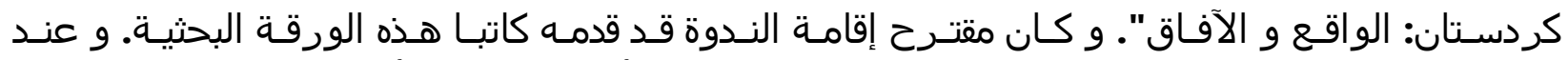

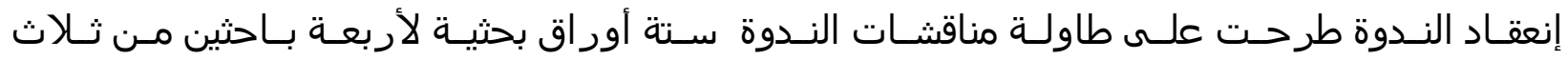

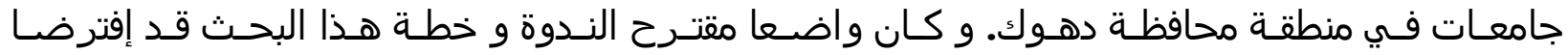

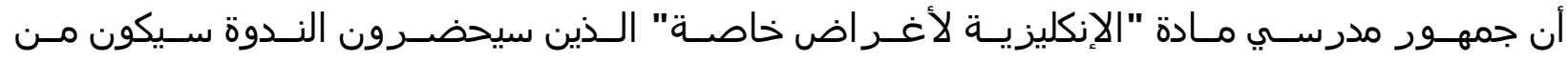

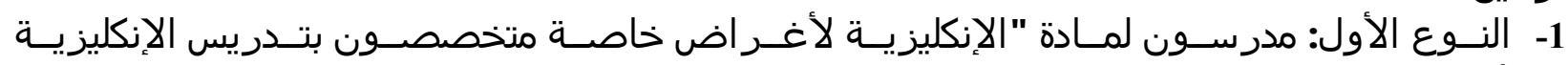
لغة أجنبية



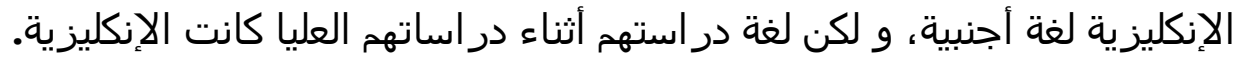

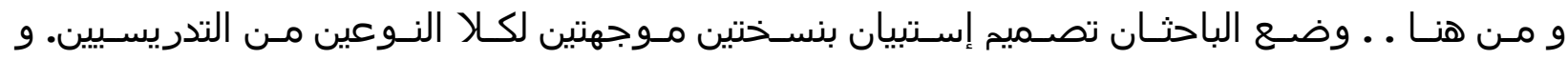

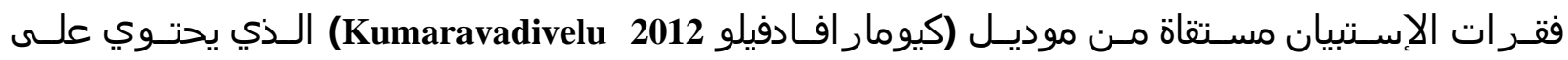



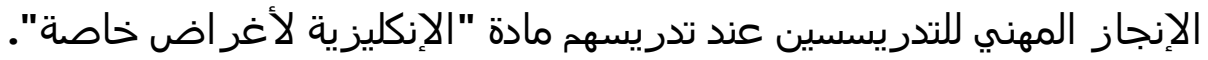

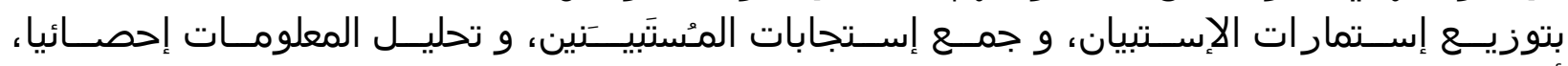
أفرز البحثس الإستنتاجات التالية:

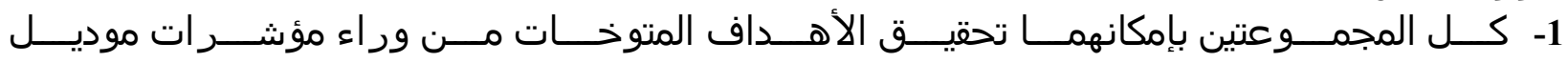

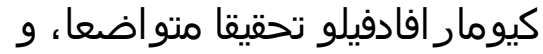

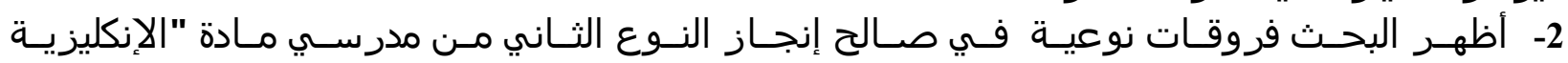

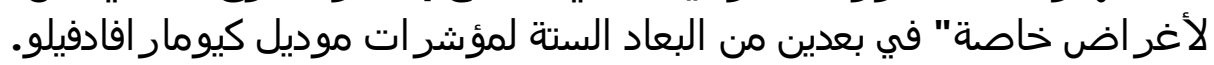

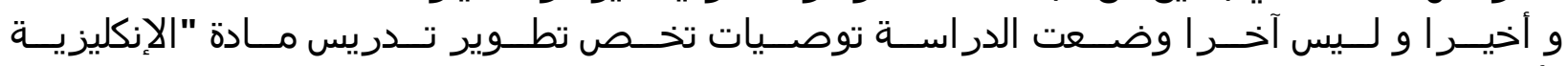

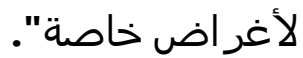

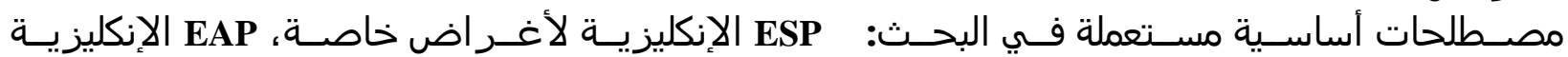

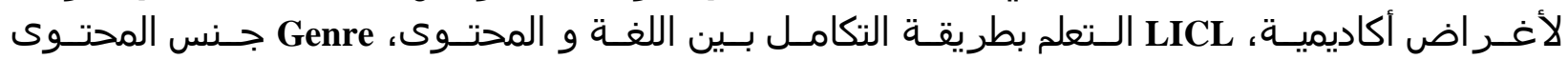

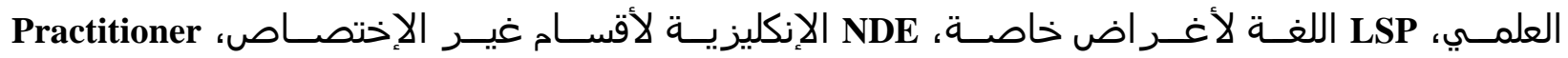
مدرس المادة العلمية بلغة غير اللغة الأمه 